\title{
The Involvement of Glutamine Synthetase/Glutamate Synthase in Ammonia Assimilation by Aspergillus nidulans
}

\author{
By MISRI B. KUSNAN, MICHAEL G. BERGER AND HEINRICH P. FOCK* \\ Fachbereich Biologie, Universität Kaiserslautern, Postfach 3049, 6750 Kaiserslautern, \\ West Germany
}

(Received 7 July 1986; revised 14 November 1986)

\begin{abstract}
Wild-type Aspergillus nidulans grew equally well on $\mathrm{NH}_{4} \mathrm{Cl}, \mathrm{KNO}_{3}$ or glutamine as the only nitrogen source. NADP+-dependent glutamate dehydrogenase (EC 1.4.1.4) and glutamine synthetase (GS; EC 6.3.1.2) activities varied with the type and concentration of nitrogen source supplied. Glutamate synthase (GOGAT) activity (EC 1.4.7.1) was detected but it was almost unaffected by the type and concentration of nitrogen source supplied. Ion exchange chromatography showed that the GOGAT activity was due to a distinct enzyme. Azaserine, an inhibitor of the GOGAT reaction, reduced the glutamate pool by $60 \%$, indicating that GOGAT is involved in ammonia assimilation by metabolizing the glutamine formed by GS.
\end{abstract}

\section{INTRODUCTION}

In the past, the elucidation of the pathway of ammonia assimilation in fungi has relied heavily on the use of mutants and on measurements of the levels and kinetic properties of the enzymes involved, particularly $\mathrm{NADP}^{+}$-dependent glutamate dehydrogenase (NADP-GDH) (EC 1.4.1.4) and glutamine synthetase (GS) (EC 6.3.1.2).

Ammonia assimilation in fungi generally occurs via the GDH pathway (Pateman \& Kinghorn, 1975), but recently some fungi have been shown to utilize the alternative GS/glutamate synthase (GOGAT) (EC 1.4.7.1) pathway (Casper et al., 1985; Dunn-Coleman et al., 1981; Limon-Lason et al., 1977; Martin et al., 1986; Roon et al., 1974). Studies on mutants of Aspergillus nidulans that lack $\mathrm{NAD}^{+}$-dependent glutamate dehydrogenase (NAD-GDH) (EC 1.4.1.2) and/or NADP-GDH have led to the suggestion that an alternative pathway of ammonia assimilation is involved in these organisms (Kinghorn \& Pateman, 1976).

Our preliminary studies of $\left[{ }^{15} \mathrm{~N}\right] \mathrm{ammonia}$ assimilation in wild-type $A$. nidulans indicated that the pattern of ${ }^{15} \mathrm{~N}$-labelling of the major amino acids was not consistent with ammonia assimilation by the GDH pathway alone (Sims \& Folkes, 1964). Here we report on the presence of GOGAT in $A$. nidulans and its possible role in ammonia assimilation in combination with GS.

\section{METHODS}

Organism. Aspergillus nidulans wild-type (DSM 63358) was obtained from Deutsche Sammlung von MikroOrganismen (Göttingen, West Germany) and maintained on malt-extract agar.

Growth conditions. The organism was grown in a modified version of the culture medium of Jennison et al. (1955) and Garrett (1972) containing $\left(\mathrm{gl}^{-1}\right)$ : glucose (10); $\mathrm{K}_{2} \mathrm{HPO}_{4} / \mathrm{KH}_{2} \mathrm{PO}_{4}(0 \cdot 96 / 0 \cdot 68), \mathrm{MgSO}_{4} .7 \mathrm{H}_{2} \mathrm{O}(0 \cdot 1), \mathrm{NaCl}$ $(0.1), \mathrm{CaCl}_{2} \cdot 2 \mathrm{H}_{2} \mathrm{O}(0.1)$, biotin $(0.001)$, riboflavin $(0.001)$, thiamin $(0.0001)$ and micronutrients according to Nicholas \& Nason (1954). Either $\mathrm{NH}_{4} \mathrm{Cl}$ (2 or $\left.50 \mathrm{mM}\right), \mathrm{KNO}_{3}(5 \mathrm{mM})$, or glutamine $(5 \mathrm{~mm})$ was used as the nitrogen source. The nitrogen source and vitamins were added separately; glutamine was filtered through a $0.22 \mu \mathrm{m}$ membrane filter (Millipore). The inoculum was prepared according to a modification of the method of Jennison et al. (1955). Mycelium with spores from the stock culture was grown in a shake culture medium

Abbreviations: GDH, glutamate dehydrogenase; GOGAT, glutamate synthase; GS, glutamine synthetase; PPT, phosphinothricin. 
containing $5 \mathrm{~mm}-\mathrm{NH}_{4} \mathrm{Cl}$ for 1 week at room temperature. Under this condition the mycelium grew to form a number of pellets. The mycelial pellets obtained were fragmented for $1 \mathrm{~min}$ in a Waring blender (Sorvall), and the resulting homogeneous suspension was filtered through a $0.5 \times 0.5 \mathrm{~mm}$ sieve and centrifuged at $2000 \mathrm{~g}$ for $5 \mathrm{~min}$. The sediment was washed twice and resuspended in distilled water to 10 times the volume of the packed fragments. The fragmented mycelium (about $150 \mathrm{mg}$ wet wt) was transferred to cylindrical culture flasks $(6.5 \times 45 \mathrm{~cm})$ containing $800 \mathrm{ml}$ culture solution. The cultures were aerated and stirred by bubbling with sterile air and the temperature was maintained by immersing the flasks in a $26^{\circ} \mathrm{C}$ water bath.

Harvest. Cultures ( $48 \mathrm{~h}$-old) were harvested by filtration through Miracloth (Calbiochem), washed with approximately $500 \mathrm{ml}$ water and weighed. Sub-samples were taken for dry wt determination and samples for enzyme analysis were frozen in liquid nitrogen and stored at $-20^{\circ} \mathrm{C}$ until use.

Incubation with inhibitors. Known amounts of mycelium from 40 to $60 \mathrm{~h}$-old cultures were transferred to a new culture solution and allowed to adapt for at least $2 \mathrm{~h}$. Thereafter, material was filtered and resuspended in fresh medium ( $1 \mathrm{~g}$ fresh wt $50 \mathrm{ml}$ ) and the inhibitor, either azaserine or phosphinothricin PPT), was added to give a final concentration of $2 \mathrm{mM}$ or $5 \mathrm{mM}$, respectively. The mycelium was harvested at intervals to allow time-course studies, filtered through Miracloth, washed with approximately $250 \mathrm{ml}$ ice-cold $0.1 \%(\mathrm{w} / \mathrm{v}) \mathrm{NaCl}$ solution and fixed in $95 \%(\mathrm{v} / \mathrm{v})$ ethanol.

Extraction of soluble nitrogen pools. The ethanolic supernatant was decanted from the fixed mycelium and adjusted with water to $60 \%(\mathrm{v} / \mathrm{v})$ ethanol. The mycelium was homogenized using a pestle and mortar. The ethanolic fraction was then remixed with homogenized mycelium and sub-samples for dry wt determination were taken. After centrifugation, the residue was further extracted with two more $30 \mathrm{ml}$ portions of $60 \%(\mathrm{v} / \mathrm{v})$ ethanol. The combined extracts were taken to dryness in a vacuum evaporator at $37^{\circ} \mathrm{C}$ and the water-soluble residue dissolved in $5 \mathrm{ml}$ water.

Separation of nitrogen compounds. Neutral and basic amino acids were separated from acidic amino acids on a Dowex 1-X8 column $(4 \times 0.9 \mathrm{~cm}$, acetate form) equilibrated with water. After washing with $8.0 \mathrm{ml}$ water, the acidic amino acids were eluted with $8.0 \mathrm{ml} 2 \mathrm{M}$-acetic acid. The water- and acid-eluates were vacuum-dried separately, and each was resuspended in $2 \mathrm{ml}$ lithium hydroxide/citric acid buffer at $\mathrm{pH} 2 \cdot 2$. The amino acids were determined using an amino acid analyser (Beckman Multichrome liquid chromatograph, model 4255 ).

Enzyme extraction. Mycelium frozen in liquid nitrogen was homogenized using a pestle and mortar. The enzymes were extracted in potassium phosphate buffer as described by Dunn-Coleman et al. (1981). The extract was desalinated on a Sephadex G-25 column equilibrated with the same buffer.

Enzyme assays. The activity of NADP-GDH was assayed in potassium phosphate buffer as described by Stewart \& Moore (1974). GOGAT was assayed according to the method of Boland \& Benny (1977) at the optimum $\mathrm{pH}$ of $8 \cdot 0$. NAD-GDH was assayed by substituting ammonium chloride for glutamine. Enzyme activity was recorded by measuring the oxidation of $\mathrm{NAD}(\mathrm{P}) \mathrm{H}$ at $340 \mathrm{~nm}\left(30^{\circ} \mathrm{C}\right)$. GS activity was determined by the synthetase test according to Ferguson \& Sims (1974); the optimum pH was $7 \cdot 4$. Protein was assayed by the Coomassie blue method (Spector, 1978) with bovine serum albumin as the standard. Specific activities of the enzymes are expressed as nmol reduced coenzyme oxidized or $\gamma$-glutamylhydroxamate formed $\mathrm{min}^{-1}\left(\mathrm{mg}^{2}\right.$ protein) $)^{-1}$.

\section{RESULTS}

\section{Activity of the glutamate-metabolizing enzymes}

The organism grew equally well in either $\mathrm{NH}_{4} \mathrm{Cl}(2$ or $50 \mathrm{~mm}), \mathrm{KNO}_{3}(5 \mathrm{~mm})$ or glutamine $(5 \mathrm{~mm})$ as the sole nitrogen source. In all cases the doubling time was about $8 \mathrm{~h}$. The pools of glutamate, glutamine and alanine were higher than those of the other amino acids analysed (data not shown) whenever the cells were grown with an abundant supply of nitrogen. Except for alanine, the amino acid contents were consistent with the observations of Robinson et al. (1973). The specific activity of NADP-GDH in a crude extract of the cells grown on either high ammonia, nitrate or glutamine was similar. However, the specific activity doubled when the cells were grown on low ammonia (Table 1). The specific activity of NAD-GDH, which was much lower than that of NADP-GDH in vitro, was similar when the cells were grown on nitrate, glutamine or ammonia. The specific activity of GS in low-ammonia- or nitrate-grown cells was slightly higher than the specific activity in cells grown on glutamine or high ammonia.

The exclusion of low $M_{\mathrm{r}}$ substances from the extract, particularly ammonia and glutamine, was found necessary in order to determine the activities of GOGAT and NAD-GDH. This was achieved by passing the crude extract through Sephadex G-25. The activity of GOGAT was NADH-dependent and hardly varied with nitrogen source (Table 1). GOGAT was strongly 

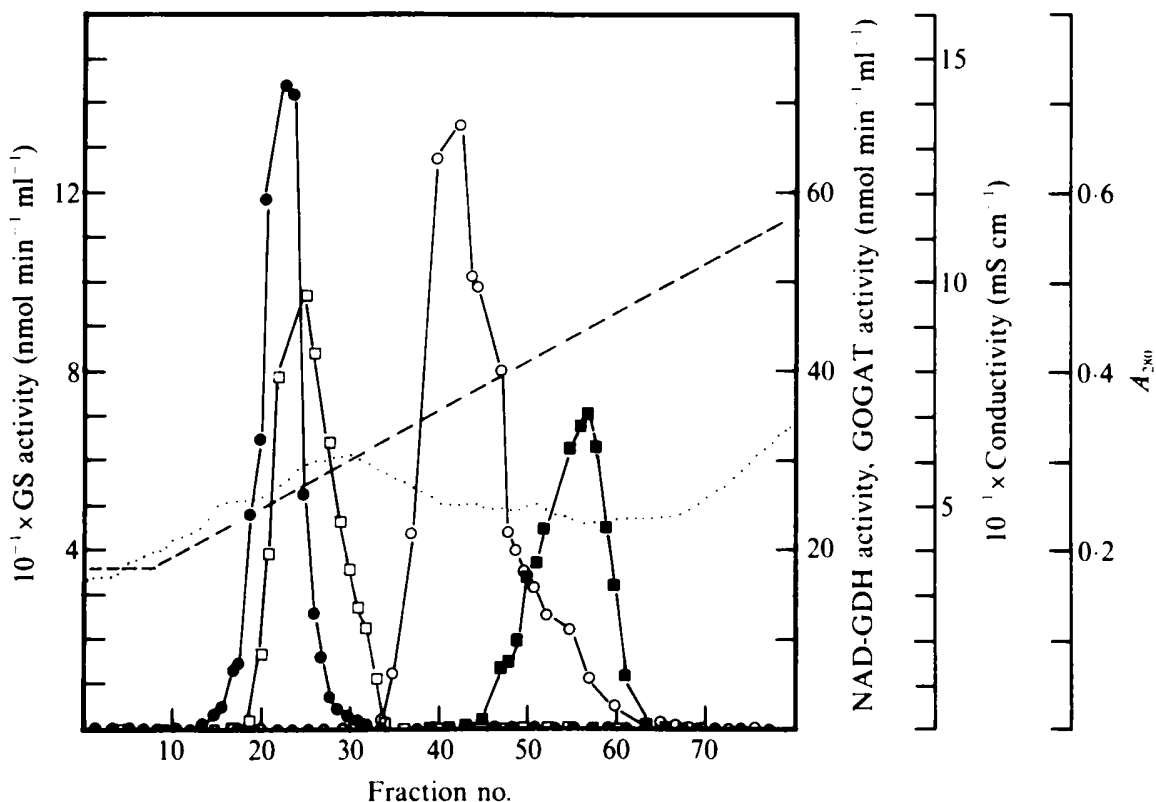

Fig. 1. Elution profile from DEAE-Sephacel of glutamate-metabolizing enzymes. Protein was precipitated from the crude extract with ammonium sulphate $(35-65 \%, \mathrm{w} / \mathrm{v}$, saturation). The pellet was resuspended in 3-4 ml extraction buffer and dialysed overnight against $20 \mathrm{~mm}$-potassium phosphate buffer, pH 7.5, containing $1 \mathrm{~mm}$-EDTA, $10 \%(\mathrm{v} / \mathrm{v})$ glycerol and $0.1 \% 2$-mercaptoethanol. The protein was absorbed onto DEAE-Sephacel $(3 \times 10 \mathrm{~cm}$ column $)$ that had been equilibrated with the same buffer. The enzymes were eluted with a linear gradient of $0-500 \mathrm{mM}-\mathrm{KCl}$ in dialysis buffer. Fractions $(6.0 \mathrm{ml})$ were collected at the rate of $25 \mathrm{ml} \mathrm{h}^{-1}$. O, NADP-GDH; $\square$, GS; O, NAD-GDH; $\square$, GOGAT: ---, conductivity; $\cdots, A_{280}$

Table 1. Protein and enzyme contents of crude extracts of $A$. nidulans grown on various nitrogen sources

Data given are from two independent experiments.

\begin{tabular}{|c|c|c|c|c|c|}
\hline \multirow[b]{2}{*}{$\begin{array}{l}\text { Nitrogen } \\
\text { source }\end{array}$} & \multirow{2}{*}{$\begin{array}{c}\text { Protein } \\
{[\mathrm{mg}(100 \mathrm{mg}} \\
\left.\text { dry } w \mathrm{t})^{-1}\right]\end{array}$} & \multicolumn{4}{|c|}{$\begin{array}{c}\text { Enzyme specific activity } \\
{\left[\mathrm{nmol} \mathrm{min}^{-1}(\mathrm{mg} \text { protein })^{-1}\right]}\end{array}$} \\
\hline & & $\begin{array}{l}\text { NADP. } \\
\text { GDH }\end{array}$ & $\begin{array}{l}\text { NAD- } \\
\text { GDH }\end{array}$ & GS & GOGAT \\
\hline $\begin{array}{c}\mathrm{NH}_{4} \mathrm{Cl} \\
(2 \mathrm{mM})\end{array}$ & $\begin{array}{l}15 \cdot 25 \\
13 \cdot 50\end{array}$ & $\begin{array}{l}665.8 \\
553.4\end{array}$ & $\begin{array}{l}24 \cdot 7 \\
41 \cdot 2\end{array}$ & $\begin{array}{l}44 \cdot 5 \\
36 \cdot 7\end{array}$ & $\begin{array}{l}20 \cdot 6 \\
33 \cdot 3\end{array}$ \\
\hline $\begin{array}{l}\mathrm{NH}_{4} \mathrm{Cl} \\
(50 \mathrm{mM})\end{array}$ & $\begin{array}{l}10 \cdot 84 \\
11 \cdot 28\end{array}$ & $\begin{array}{l}267 \cdot 7 \\
177 \cdot 3\end{array}$ & $\begin{array}{l}12 \cdot 7 \\
12 \cdot 2\end{array}$ & $\begin{array}{l}18.9 \\
24 \cdot 5\end{array}$ & $\begin{array}{l}10.8 \\
24.9\end{array}$ \\
\hline $\begin{array}{l}\mathrm{KNO}_{3} \\
(5 \mathrm{mM})\end{array}$ & $\begin{array}{l}11 \cdot 63 \\
12.82\end{array}$ & $\begin{array}{l}371 \cdot 3 \\
297 \cdot 7\end{array}$ & $\begin{array}{l}20.8 \\
14.9\end{array}$ & $\begin{array}{l}64 \cdot 5 \\
29 \cdot 9\end{array}$ & $\begin{array}{l}27 \cdot 7 \\
13 \cdot 6\end{array}$ \\
\hline $\begin{array}{l}\text { Glutamine } \\
(5 \mathrm{~mm})\end{array}$ & $\begin{array}{r}9.95 \\
12.01\end{array}$ & $\begin{array}{l}233 \cdot 3 \\
283 \cdot 3\end{array}$ & $\begin{array}{l}21 \cdot 2 \\
21 \cdot 5\end{array}$ & $\begin{array}{l}27 \cdot 1 \\
28 \cdot 0\end{array}$ & $\begin{array}{l}15.9 \\
28.9\end{array}$ \\
\hline
\end{tabular}

inhibited by azaserine in vitro $(0 \cdot 1 \mathrm{mM}$ caused about $80 \%$ inhibition $)$. In contrast, the activities of NAD- or NADP-GDH were not affected by azaserine (data not shown). This indicated that the GOGAT and the NAD- and NADP-GDH activities tested were not catalysed by the same enzyme. To confirm this protein precipitated from the extract was loaded onto DEAE-Sephacel and eluted with a linear $\mathrm{KCl}$ gradient (Fig. 1): the elution profile clearly showed two separate peaks and one overlapping peak of glutamate-metabolizing enzymes. The NADP-GDH and GS 


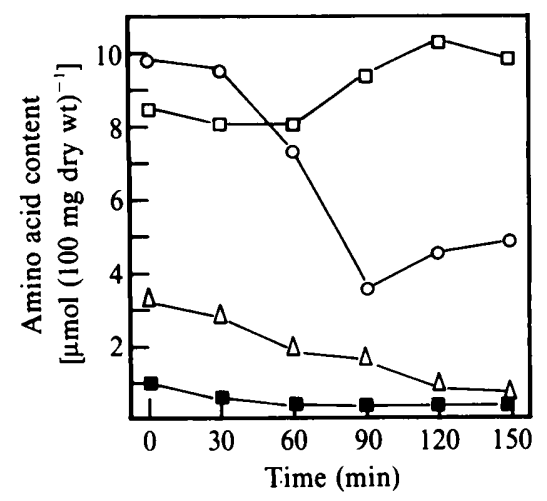

Fig. 2. Effect of $2 \mathrm{mM}$-azaserine added at zero time on the amino acid pools of $A$. nidulans grown on 5 mM-glutamine as nitrogen source. $\square$, Glutamine; $O$, glutamate; $\triangle$, alanine; $\square$, aspartate. The results of an experiment typical of two with similar trends are shown; the average deviation from the value shown of the means of replicate analyses was about $10 \%$. The pool sizes of amino acids in the control experiment were similar to those at the beginning of the experiment shown.

Table 2. Specific activities of glutamate-metabolizing enzymes from a mutant of A. nidulans that lacks NADP-GDH

The mutant (ATCC 26457; pabaA-1 gdhA-10) was grown at $30^{\circ} \mathrm{C}$ in media as described in Methods with the addition of $1 \mathrm{mg} p$-aminobenzoic acid $1^{-1}$. The sole nitrogen source was $\mathrm{NH}_{4} \mathrm{Cl}(2$ and $50 \mathrm{mM})$. The values are means of three replicates $( \pm \mathrm{SE})$.

\begin{tabular}{lcc}
\multicolumn{1}{c}{$\begin{array}{c}\text { Specific activity } \\
\text { Enzyme }\end{array}$} & $\overbrace{2 \mathrm{mM}-\mathrm{NH}_{4} \mathrm{Cl}} 50 \mathrm{mM}-\mathrm{NH}_{4} \mathrm{Cl}$ \\
NADP-GDH & 0 & 0 \\
NAD-GDH & $38.6( \pm 3 \cdot 2)$ & $29.5( \pm 6.3)$ \\
GS & $63.5( \pm 6 \cdot 1)$ & $35.7( \pm 5.6)$ \\
GOGAT & $9.0( \pm 2.6)$ & $14.7( \pm 3.7)$
\end{tabular}

peaks overlapped and eluted well ahead of NAD-GDH and GOGAT. NAD-GDH and GOGAT overlapped only slightly which clearly demonstrated that GOGAT is a distinct enzyme in $A$. nidulans.

GOGAT activity was also detected in a mutant of $A$. nidulans that lacks NADP-GDH. The activity of GOGAT and also of NAD-GDH hardly changed with the amount of ammonia supplied. However, the activity of GS doubled when the mutant was grown on low ammonia (Table 2).

\section{Effect of azaserine}

The effect of this inhibitor ( $2 \mathrm{mM}$ ) on the cell amino acid content was examined in cells grown with glutamine. The results of replicate analyses of a typical experiment are shown in Fig. 2 . The glutamine content was relatively unchanged during the $150 \mathrm{~min}$ incubation period but the glutamate content declined from about $10 \mu \mathrm{mol}$ after $30 \mathrm{~min}$ to about $4 \mu \mathrm{mol}$ after $90 \mathrm{~min}$. The alanine and aspartate contents were reduced to one-half and one-third, respectively. The amino acid content of controls without inhibitor remained unchanged (data not shown). Two independent experiments showed a similar pattern of inhibition although the extent was different.

The effect of azaserine on the amino acid content of cells grown on 2 and $50 \mathrm{~mm}$-ammonia is shown in Fig. 3. The glutamate pool declined from about 6 and $5 \mu \mathrm{mol}$ to constant contents of 3 and $2 \mu \mathrm{mol}$ after $60 \mathrm{~min}$ incubation, in 2 and $50 \mathrm{~mm}$-ammonia-grown-cells, respectively. At low ammonia, the glutamine content increased from about $7.0 \mu \mathrm{mol}$ to $12 \mu \mathrm{mol}$ after $30 \mathrm{~min}$, but 


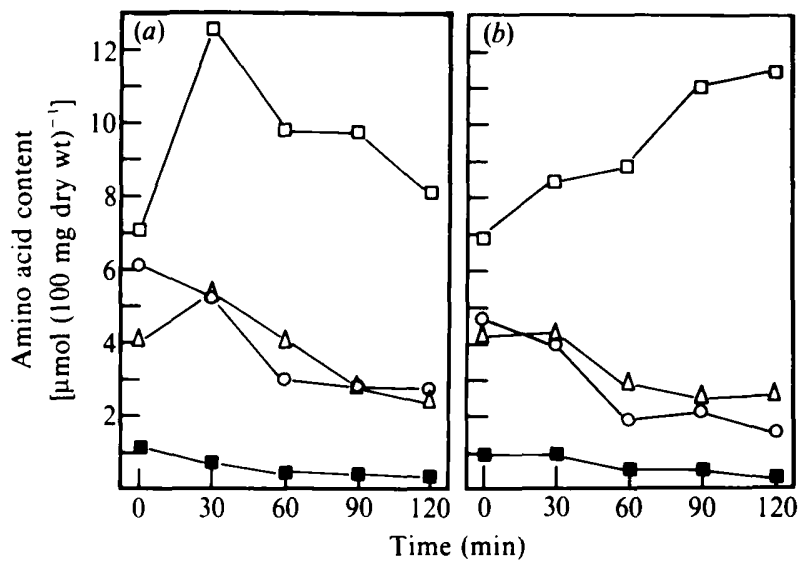

Fig. 3. Effect of $2 \mathrm{~mm}$-azaserine added at zero time on the amino acid pools of $A$. nidulans grown on $2 \mathrm{mM}$ (a) and $50 \mathrm{~mm}(b) \mathrm{NH}_{4} \mathrm{Cl}$ as nitrogen source. $\square$, Glutamine; $\bigcirc$, glutamate; $\triangle$, alanine; $\square$, aspartate. The results of an experiment typical of two with similar trends are shown; the average deviation from the value shown of the means of replicate analyses was about $10 \%$. The pool sizes of amino acids in the control experiment were similar to those at the beginning of the experiment shown.

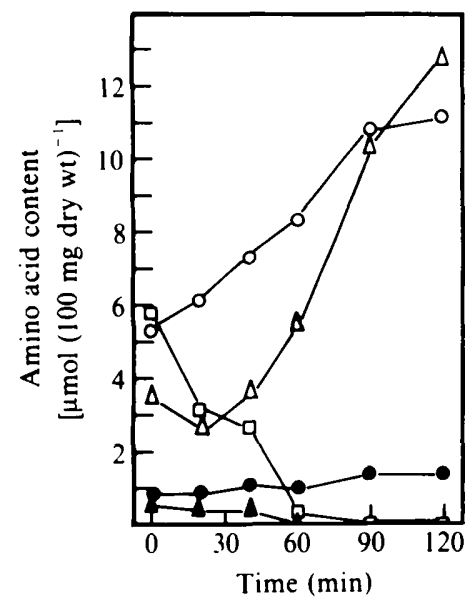

Fig. 4. Effect of $5 \mathrm{mM}$-PPT added at zero time on the amino acid pools of $A$. nidulans grown on $2 \mathrm{~mm}$ $\mathrm{NH}_{4} \mathrm{Cl}$ as nitrogen source. $\square$, Glutamine; $O$, glutamate; $\triangle$, alanine; $O$, aspartate; $\Delta$, asparagine. The results of an experiment typical of two replicates with similar trends are shown; the average deviation from the value shown of the means of replicate analyses was $10 \%$. The pool sizes of amino acids in the control experiment were similar to those at the beginning of the experiment shown.

then slowly declined to the previous concentration after 120 min (Fig. $3 a$ ). However, on high ammonia, the glutamine content continued to increase during the whole 120 min incubation period (Fig. $3 b$ ). The aspartate and alanine pools were reduced to about one-half after $120 \mathrm{~min}$ incubation both on low and high ammonia.

Low-ammonia-grown cells were also incubated with 5 mM-PPT (inhibitor of GS; Fraser \& Ridley, 1984; Wild \& Manderscheid, 1984). Under these conditions, the glutamine pool rapidly decreased and could hardly be detected after 90 min incubation (Fig. 4). On the other hand, $5 \mathrm{~mm}$-methionine sulfoximine (MSO), an inhibitor of GS commonly used in plant biochemistry, inhibited the extracted enzyme completely, but had no effect in vivo, suggesting that the cells either detoxified, or did not take up, this inhibitor. The asparagine content was reduced to almost zero after $90 \mathrm{~min}$ incubation, due either to a direct effect of PPT on asparagine 
synthetase, or due indirectly to a decreased glutamine content. However, the glutamate and alanine contents were about two- and three-fold higher after $120 \mathrm{~min}$, respectively. Changes in the aspartate and alanine pools (Figs 2 and 3 ) could probably be explained by the activity of an aminotransferase, since the pool size was very dependent on the glutamate content.

\section{DISCUSSION}

The observation that a marked derepression of NADP-GDH synthesis takes place in several yeasts (Burn et al., 1974), and in Neurospora crassa and A. nidulans (Pateman, 1969; see also Table 1), in environments containing low concentrations of ammonia, has led to the conclusion that NADP-GDH is the primary enzyme involved in glutamate formation in fungi. The large accumulation of glutamate observed in the presence of the GS inhibitor PPT (Fig. 4) indicates that glutamate, the precursor of glutamase, is presumably also being synthesized by NADPGDH. The important role of NADP-GDH in ammonia assimilation has been confirmed by investigations on Cenococcum graniforme and Candida utilis (Genetet et al., 1984; Sims \& Folkes, 1964).

This study indicates that the formation of glutamate in wild-type $A$. nidulans is brought about by concurrent activity in the GDH pathway and in the alternative pathway(s), since incubation of $A$. nidulans with azaserine reduced the glutamate pool by about $60 \%$ when the organism was grown on either glutamine (Fig. 2) or ammonia (Fig. 3a,b). Complete depletion of glutamate did not occur. The low residual glutamate content (Fig. $3 a, b$ ) was possibly due to an amination reaction catalysed by NADP-GDH, since the in vitro NAD- and NADP-GDH activities were not affected by azaserine (data not shown; Miflin \& Lea, 1975). Alternatively, in the glutaminegrown cells, glutamine could be hydrolysed by glutaminase. The presence of glutaminase has been reported in some fungi (Imada et al., 1973). There was no glutaminase activity detected in $A$. nidulans when the cells were grown on glutamine (data not shown). However, this does not exclude the possibility that glutaminase is being activated or induced after the alternative pathway(s) was inhibited.

In experiments with the inhibitor azaserine, the decrease in glutamate was always associated with an increase in glutamine (Fig. 3). This is evidence that glutamine is a precursor of glutamate (Miflin \& Lea, 1980). However, the pattern of glutamine increase under conditions of low ammonia (Fig. $3 a$ ) differed from that where ammonia was abundant (Fig. $3 b$ ), an observation which cannot be explained at the present time.

Thus, the alternative pathway(s) to the NADP-GDH pathway also utilized glutamine as a precursor. Glutamine appears to be metabolized by a 'coupled reaction' of glutamine transaminase and $\omega$-amidase; the released ammonia and 2-oxoglutarate are then reassimilated into glutamate by GDH (Calderón \& Mora, 1985). The activity of $\omega$-amidase is inhibited by 6diazo-5-oxo-L-norleucine (DON) (Calderón $e t$ al., 1985) and possibly also by azaserine, a potent inhibitor of a wide range of glutamine-using enzymes that transfer amide groups (Miflin \& Lea, 1980). While the contribution of the 'coupled reaction' of glutamine aminotransferase and $\omega$ amidase in glutamine assimilation in $A$. nidulans grown on glutamine cannot be ruled out, glutamine could also be converted directly into glutamate via the GOGAT pathway without contributing to the formation of free ammonia, since significant GOGAT activity was detected (Table 1). Evidently, GOGAT plays a major role in glutamine assimilation in $N$. crassa grown on glutamine (Calderón \& Mora, 1985). Furthermore, the pool of glutamate in low- and highammonia-grown cells was also reduced. This indicates that the decrease in the glutamate pool was due to a decrease in glutamate formed from glutamine rather than to the non-availability of ammonia. This strongly supports the suggestion that the role of the GOGAT pathway is to provide glutamate from glutamine, either present in the medium or newly synthesized by the GS pathway, when ammonia is utilized as the nitrogen source. Because no activity of NADP-GDH was detected in an $A$. nidulans mutant that lacks NADP-GDH (Table 2), the role of GS/GOGAT is expected to be important in glutamate synthesis in this mutant. Although substantial amounts of NAD-GDH activity were detected in the mutant this enzyme is considered to function mainly in deamination (Kinghorn \& Pateman, 1977). 
The relative contribution of the two pathways to the synthesis of glutamate when grown on either low or high ammonia seems to be maintained since there is a similar reduction of the glutamate pool in the presence of excess glucose (Fig. $3 a, b$ ). This is possibly achieved by regulating the synthesis both of NADP-GDH and GS (Table 1). The contribution of the two pathways in providing glutamate in wild-type $A$. nidulans will be elucidated in later experiments using [ $\left.{ }^{15} \mathrm{~N}\right] \mathrm{ammonia}$.

We are grateful to Farbwerke Hoechst AG (Frankfurt/M., West Germany) for kindly supplying us with phosphinothricin, Dr G. C. Bate for helpful discussion and Deutscher Akademischer Austauschdienst for financial assistance to $M$. B. Kusnan.

\section{REFERENCES}

Boland, M. J. \& BENNY, A. G. (1977). Enymes of nitrogen metabolism in legume nodules. Purification and properties of NADH-dependent glutamate synthase from lupin nodules. European Journal of Biochemistry 79, 355-362.

Burn, V. J., TuRner, P. R. \& Brown, C. M. (1974). Aspects of inorganic nitrogen assimilation in yeasts. Antonie van Leeuwenhoek 40, 93-102.

Calderón, J. \& Mora, J. (1985). Glutamine cycling in Neurospora crassa. Journal of General Microbiology 131, 3237-3242.

Calderón, J., Morett, E. \& Mora, J. (1985). $\omega$ Amidase pathway in the degradation of glutamine in Neurospora crassa. Journal of Bacteriology 161, 807809.

Casper, P., Bode, R. \& Birnbaum, D. (1985). Untersuchungen zur Regulation der Ammoniumassimilation von Candida maltosa. Journal of Basic Microbiology 25, 95-101.

DunN-Coleman, N. S., Robey, E. A., Tomsett, A. B \& GARRETT, R. H. (1981). Glutamate synthase levels in Neurospora crassa mutants altered with respect to nitrogen metabolism. Molecular and Cellular Biology 1, 158-164.

Ferguson, A. R. \& Sims, A. P. (1974). The regulation of glutamine metabolism in Candida utilis: the role of glutamine in the control of glutamine synthetase. Journal of General Microbiology 80, 159-171.

Fraser, A. R. \& Ridley, S. M. (1984). Kinetics for glutamine-synthetase inhibition by phosphinothricin and measurement of other enzyme activities in situ in isolated asparagus cells using a freeze-thaw technique. Planta 161, 470-474.

GARRETT, R. H. (1972). The induction of nitrate reductase in Neurospora crassa. Biochimica et biophysica acta 264, 481-489.

Genetet, I., Martin, F. \& Stewart, G. R. (1984). Nitrogen assimilation in mycorrhizas. Ammonium assimilation in the $\mathrm{N}$-starved ectomycorrhizal fungus Cenococcum graniforme. Plant Physiology 76, 395-399.

Imada, A., Igarasi, S., Nakahama, K. \& Isono, M. (1973). Asparaginase and glutaminase activities of micro-organisms. Journal of General Microbiology 76, 85-99.

Jennison, M. W., Newcomb, M. D. \& Henderson, R. H. (1955). Physiology of the wood-rotting basidiomycetes. I. Growth and nutrition in submerged culture in synthetic media. Mycologia 47, 155-274.
Kinghorn, J. R. \& Pateman, J. A. (1976). Mutants of Aspergillus nidulans lacking nicotamide adenine dinucleotide-specific glutamate dehydrogenase. Journal of Bacteriology 125, 42-47.

KinghoRn, J. R. \& PAteman, J. A. (1977). Nitrogen metabolism. In Genetics and Physiology of Aspergillus, pp. 147-202. Edited by J. E. Smith \& J. A. Pateman. London: Academic Press.

Limon-Lason, J., LaRa, M., Resendiz, B. \& Mora, J. (1977). Regulation of glutamine synthetase in fedbatch cultures of Neurospora crassa. Biochemical and Biophysical Research Communications 78, 12341240.

Martin, F., Stewart, G. R., Genetet, I. \& Letacon, F. (1986). Assimilation of ${ }^{15} \mathrm{NH}_{4}$ by beech (Fagus sylvatica L.) ectomycorrhizas. New Phytologist 102, 85-94.

MifLIN, B. J. \& LEA, P. J. (1975). Glutamine and asparagine as nitrogen donors for reductant-dependent glutamate synthesis in pea roots. Biochemical Journal 149, 403-409.

MifLin, B. J. \& LEA, P. J. (1980). Ammonia assimilation. In The Biochemistry of Plants, vol. 5, pp. 169202. Edited by B. J. Miflin. London: Academic Press.

Nicholas, D. J. D. \& Nason, A. (1954). Mechanism of action of nitrate reductase from Neurospora. Journal of Biological Chemistry 211, 183-197.

Pateman, J. A. (1969). Regulation of synthesis of glutamate dehydrogenase and glutamine synthetase in micro-organisms. Biochemical Journal 115, 769775.

Pateman, J. A. \& Kinghorn, J. R. (1975). Nitrogen metabolism. In The Filamentous Fungi, vol. 2, pp. 159-237. Edited by J. E. Smith \& D. R. Berry. London: Edward Arnold.

Robinson, J. H., Anthony, C. \& Drabble, W. T. (1973). Regulation of the acidic amino-acid permease of Aspergillus nidulans. Journal of General Microbiology 79, 65-80.

ROON, R. J., Even, H. L. \& LARIMORE, F. R. (1974). Glutamate synthase: properties of the reduced nicotinamide adenine dinucleotide-dependent enzyme from Saccharomyces cerevisiae. Journal of Bacteriology 118, 89-95.

Sims, A. P. \& FolkEs, B. F. (1964). A kinetic study of the assimilation of ${ }^{15} \mathrm{~N}$-ammonia and the synthesis of amino acids in an exponentially growing culture of Candida utilis. Proceedings of the Royal Society B159, 479-502. 
SPECTOR, T. (1978). Refinement of the Coomassie blue method of protein quantitation. Analytical Biochemistry 86, 142-146.

Stewart, G. R. \& Moore, D. (1974). The activities of glutamate dehydrogenases during mycelial growth and sporophore development in Coprinus lagopus (sensu Lewis). Journal of General Microbiology 83, 73-81.

WILD, A. \& Manderscheid, R. (1984). The effect of phosphinothricin on the assimilation of ammonia in plants. Zeitschrift für Naturforschung 39, 500-504. 